\title{
THE PROFESSIONAL ATHLETE: LIBERTY OR PEONAGE?
}

\author{
DANIEL I. SHAPIRO*
}

A close scrutiny of the contractual relationship of the North American professional athlete with his team reveals serious restraints on the player's ability to freely choose his employer. The author presents a detailed analysis of the four basic restrictions used in the major professional sports: the reserve system, the player draft, blacklisting, and the registration list. He then discusses current and proposed antitrust legislation in Canada and the United States, all of which appears to have little serious effect on the restraints which, the author suggests, violate antitrust law. In conclusion the author comments on the soundness of traditional arguments used to support such restrictions, and suggests that presently the only means available to athletes to challenge the stranglehold of clubs and leagues is through negotiation and possibly player strikes.

\section{INTRODUCTION}

The ordinary man expects that, with success in his field, he can gain an increasing measure of personal freedom. The realization of such a hope is, in fact, largely denied to the professional athlete.

It shall be my purpose in this paper to examine the legal effect of the existing restraints presently placed on the professional athlete in Canada and the United States. I shall then look at how each type of restrictive measure is applied in the major sports of this continent. Also, I shall examine some of the popular myths and prevailing attitudes as to the desirability of imposing restraints on professional athletes, and make a few personal observations in the process.

I have attempted to make the content of this paper as Canadianoriented as possible, but the task has been onerous. From the outset, it is important to note that it was necessary to draw heavily from United States writings and jurisprudence for the simple reason that most of the major sports teams are U.S.-based and as a result are governed and challenged by that country's laws. For the most part, the actual operation of the restraints in Canada are identical to those employed in the U.S., but the cases contesting the restraints are almost exclusively American. Having made this observation, I shall proceed.

\section{COMMON LAW}

All the restraints that shall be considered quite naturally arise out of contractual obligations between the player and the team. It is not my purpose in this paper to discuss contractual implications at length; however, a cursory look at the basic principles is necessary.

Invariably, each sport uses a standard player contract. For a fee, the player becomes the property of the club, and in the writer's opinion, under undue restraints.

A player may seek to breach the contract for any number of reasons. The club has three remedies at law: (1) specific performance; (2) damages; and (3) injunction. 
An athletic contract is a contract of service and, with few exceptions, the courts will not decree specific performance for such a contract. ${ }^{1}$

The second remedy is damages. The innocent party to a breach of contract may accept the repudiation and sue for damages for the loss of his bargain. However, assessing damages for contracts of personal service is invariably a most difficult task. ${ }^{2}$

When the loss of a person's services cannot reasonably or adequately be compensated in damages, then an injunction may be issued preventing that person from offering his services to anyone else. A court may, by injunction, restrain a contracting party from committing a breach of contract, provided that the effect of such an order does not directly or indirectly compel the defendant to do acts which he could not have been ordered to do by a decree of specific performance. As damages are often difficult to ascertain, when a breach of contract arises the injunction is frequently used. Needless to say, the matter of injunctions is complex and any further discussion is not within the scope of this paper. ${ }^{3}$

\section{PERTINENT LEGISLATION}

The common law of contracts, specifically contracts in the restraint of trade, is supplemented by statute. When considering the restraints existing on an athlete, you must consider antitrust laws. These laws govern commercial activities thereby including professional sports.

In Canada, the governing antitrust legislation is the Combines Investigation Act, ${ }^{4}$ which, with a few minor changes, has been the guiding directory in this field for over forty years. The general tenor of this Act is to prevent price-fixing or corporate conspiracy in setting or regulating the consumer markets. Section $32(1)^{5}$ is the pertinent section to consider in dealing with the present topic:

32(1). Everyone who conspires, combines, agrees or arranges with another person ...

(c) to prevent, or lessen, unduly, competition in the production, manufacture, purchase, barter, sale, storage . . . or supply of an article, ...

(d) to restrain or injure trade or commerce in relation to any article is guilty of an indictable offense and is liable to imprisonment for two years.

However, this section has been interpreted as not applying to the service industry, ${ }^{6}$ and since athletic contracts are service contracts, virtually no antitrust law is applicable to check violations of commercial restraints in the area of athletics.

The only other piece of Canadian legislation touching on antitrust implications is the Criminal Code, ${ }^{7}$ specifically section $424(1)$ on conspiracy in restraint of trade. It states:

424(1). A conspiracy in restraint of trade is an agreement between two or more persons to do or to produce to be done any unlawful act in restraint of trade.

' Johnson v. Shrewsbury and Birmingham Ry. (1853) 3 D.M. \& G. 358 cf. Taylor v. N.U.S. (1967) 1 W.L.R. 532.

2 Treitel, Law of Contract 787.788 and 795-796 (3d ed.).

3 Id. at $850-854$ for further comments.

1 R.S.C., c.314, s.1.

5 Part V. Offences in Relation To Trade.

- The Queen v. K. J. Beamish Construction Co. Led., et al. 1968) 2 C.C.C. 5.

7 R.S.C. 1970, c. C.34. 
How effective a measure this section might be is a matter of conjecture. It has never been tested vis-à-vis athletics, to my knowledge.

The last relevant piece of legislation to consider is the Canadian Bill of Rights. ${ }^{8}$ Because it has an overriding effect when speaking of freedom and liberties, I would ask the reader to consider the proposition that the restraints placed upon a professional athlete are in violation of this Act.

\section{Section 1 of the Canadian Bill of Rights states:}

1. It is hereby recognized and declared that in Canada there have existed and shall continue to exist without discrimination by reason of race, national origin, colour, religion or sex, the following human rights and fundamental freedoms, namely:

(a) The right of the individual to life, liberty, security of the person and enjoyment of property, and the right not to be deprived thereof except by due process of law;

I would isolate the phrase "the right of the individual to life, liberty and security of the person". "Liberty" is defined in Webster's New International Dictionary, second edition, as follows:

-freedom from external restraint or compulsion; power to do as one pleases

-state or fact of being a free person; exemption from subjection to the will of another

claiming ownership of the person or services-eg. slavery, serfdom, bondage, etc.

Among a myriad of definitions, interpretations and explanations of liberty and in particular this phrase of the Canadian Bill of Rights, I would submit, perhaps presumptuously, that included in a person's pursuit of liberty is his right to seek and leave employment in areas where he is qualified to do so. With a few contractual exceptions, ${ }^{9}$ I know of no vocation where a person must remain employed if that person desires not to remain with a particular employer. The one exception is the professional athlete. By virtue of a few contractual restraints, unknown to other areas of commercial law, as well as a few "unwritten" restrictions, the North American professional athlete virtually gives up his liberty when he signs his contract. He becomes a chattel. I shall elaborate more fully later in the paper.

In the United States, the antitrust legislation is embodied in the Sherman Act ${ }^{10}$ and when discussing the conflict that exists between professional sports and federal antitrust laws, the sections usually violated are one and two.

\section{Section 1 of the Sherman Act provides in part:}

Every contract, combination in the form of trust or otherwise, or conspiracy, in restraint of trade or commerce among the several states ... is declared to be illegal ....

\section{Section 2 provides in part:}

Every person who shall monopolize, or attempt to monopolize, or combine or conspire with any other person or persons, to monopolize any part of the trade or commerce among the several states ... shall be deemed guilty of a misdemeanor....

As will be seen in the American cases, almost all actions are brought pursuant to the Sherman Act.

B.S.C. 1970 (Appendix III).

9 Quite obviously a contract for a specified length of time will bind both parties despite a lack of desire to be bound by either party. Of course, it can be breached if so desired. However, seldom do contracts in commer. cial areas provide for the possibility of perpetual employment with one employer as do many professional athletic contracto.

1015 U.S.C. 1292. 


\section{THE RESTRAINTS}

There are four basic restraints placed on the North American professional athlete:

1. the reserve system, which includes reserve or option clauses in the player's contract;

2. the player draft;

3. blacklisting;

4. the negotiation list.

At least the first three categories exist in every major sport ${ }^{11}$ being played in Canada and the United States. I will now consider each in detail, making my initial comments applicable to the United States and then Canada, where distinctions between the two countries exist.

\section{The Reserve System}

The term "reserve clause" is often used in professional sports, but what is involved is more a system than a clause. Basically, the reserve system consists of a group of related contractual provisions which give the club holding the contract an exclusive, perpetual option on the player's services, implemented and reinforced by league rules under which all clubs agree not to employ a player under reservation to another club. ${ }^{12}$ The result is that once a player has signed a contract with a club, he is committed to continued renegotiation for his services with that same organization. Each year, the club, within certain limits regarding salary adjustments, may renew a player's contract. If the player does not like the new terms, he is not free to sell his services to another club; instead he can only seek to have his contract sold or traded to another team, or he may retire or play out his "option" (a hybrid of the reserve clause), depending on the sport. ${ }^{13}$ On the other hand, the employer club, at any time, can assign a player's contract, without his consent, to any other club, or may obtain an injunction to prohibit the player from playing for any other team, if he breaches his contract. As well, a team may automatically renew a player's contract at a lesser salary than that paid the previous year, and may continue to renew the contract perpetually, if the player cannot come to an agreement with the team for the upcoming season. ${ }^{14}$

Treitel has written: 15

When speaking in purely contractual terms, a reserve clause is in essence a covenant. A covenant in restraint of trade is invalid unless three conditions are satisfied; there must be an interest meriting the protection; the restraint must be reasonable; and it must not be contrary to the public interest.

If we can conclude that a reserve clause in a professional athletic contract does not violate these conditions, then such a clause could not be deemed as contributing to a restraint of trade. An investigation of case authority later in the paper will deal with this "supposition".

R. S. Nozick, in his unpublished master's of law thesis, viewed the reserve clause slightly differently: ${ }^{16}$

While the reserve clause may or may not be legal on purely contractual grounds, it is

"The major sports to be considered are baseball, basketball, football and hockey.

12 Allison, Professional Sports and the Antitrust Laws: Status of the Reserve System, (1973) 25 Baylor Law Review 1 at 18.

13 Martin, Labor Controversy in Pro Baseball: The Flood Case, (1972) 23 Labor Law Journal 567 and 568.

14 Supra, n. 12 at 19.

is Supra, n. 2 at 378.

16 Nozick, Recent Proposals in Canadian Antitrust Law (1971) at 110. 
clear that the courts will not grant specific performance for a contract of service. ${ }^{17}$ Thus while a player may be in breach of contract, he clearly has the right to play for another team, although he may have to pay damages. It is thus the refusal of the other teams to hire that player which makes the reserve clause effective, and not the clause itself.

What Mr. Nozick suggests is that the "blacklisting" restraint used by the clubs in a league makes the reserve clause a viable force.

The reserve clause or reserve system is used in ali the major sports, but not all use it in the same form. As mentioned earlier, there is a hybrid of this system known as the "option clause". It is indigenous to professional football, hockey and basketball, in both Canada ${ }^{18}$ and the United States.

The option clause or system is not as restrictive as the classic reserve clause or system. Once a player is drafted or is signed by a club, he may not negotiate or sign with any other team; he is bound to that club for the term of the contract plus one option period, which is invariably a season. Of course, a club may freely assign the player's contract to another club without his consent. When a player's contract comes up for renewal, if he and the team do not come to terms, he may "play out his option". What this means is that the team has the option of automatically renewing the contract for the original contractual period ${ }^{19}$ at a lesser amount than the previous year. ${ }^{20}$ After playing out his option, the player then becomes a "free agent", which means he may freely negotiate with any other team in the league. ${ }^{21}$

The option clause system would initially seem to be somewhat "fairer" to the athlete than the reserve clause system (in its strictest form), setting aside for the moment that both would appear, I suggest, to be quite blatantly in violation of antitrust policy. However, in practise, becoming a free agent is not that easy. Although the contract states that the option may not be extended after its expiration, it can be revitalized when a new contract is signed, and in almost every case the athlete is "forced" to sign a new contract. Two further restraints contribute to this forced signing. There appears to be an unwritten agreement among the team owners, in both countries, that no other club will deal with a player who plays out his option. This is invariably, though not always, the case. Often Canadian football players will play out their option and go to the National Football League in the States, but seldom, if ever, will they go to another Canadian team, mainly because no other Canadian team will sign them.

The second restraint is evident in the National Football League, but it is not (to the writer's knowledge) in existence in the Canadian Football League. After an N.F.L. player has played out his option, any new club that signs that player must provide compensation to his former club. ${ }^{22}$ The most notable example of this restraint was in the case of Dave Parks, who, as an All-Pro receiver with the San Francisco 49ers, played out his option with that team and then signed with the New Orleans Saints. The league commissioner, Pete Rozelle, ordered the

17 Supra, n. 1.

to Canada has no professional basketball league.

19 The great majority of contracts are for one year, so the option period is also one year. Even where the original contract is a long term one, the option period is generally left at one year by consent of both parties.

20 See Appendix I for contracts of N.F.L. and C.F.L.

21 Supra, n. 12 at 20-21.

22 Constitution and By-Laws for the N.F.L. Art. XII, 12.1 (H) (1972). 
Saints to surrender their 1968 and 1969 first round draft choices to the $49 \mathrm{ers}$ as compensation. By that precedent, a player who has played out his option must now convince a new team that he is worth not only the salary he is seeking, but also the loss of any player on the new team whom the commissioner, in his total and unappealable discretion, considers to be adequate compensation for the player's old team. It is suggested that the effect of the "Rozelle Rule" is a severe restraint of trade in contravention of the Sherman Act. ${ }^{23}$ This rule has recently been attacked in a suit filed by the N.F.L. Players Association against the N.F.L. charging the league with violation of the Sherman Act. ${ }^{24}$

It would appear quite obviously that the effect of the reserve clause violates antitrust legislation, by eliminating a player's ability to bargain with his employers for his services; however, before we review the case authority, I shall analyze the other restraints.

\section{The Player Draft}

The restraining effect of the reserve and option clauses upon the bargaining positions of the players has been further intensified by the uniform player drafts. A form of player draft is currently used by all the professional sports leagues. Due to the existence of two rival leagues in basketball and hockey, these sports actually have two drafts, one by each league. This affords the player the limited choice of the league he would like to play with and the benefit of bargaining one league against the other. However, in baseball and football, there is only one draft within each sport. ${ }^{25}$

Basically, the draft system operates in the following manner in all sports. Each year amateur athletes graduate from amateur ranks, usually college (junior ranks in hockey), and become eligible to play professionally. In order to prevent an "imbalance" between teams in a league, teams are not allowed to hire any player they wish, but must rather select or "draft" the players with whom they wish to negotiate. Such a selection depends on that team's standing in the league at the end of the particular sport's season. The last place team gets the first pick of the eligible athletes, the second last team gets the second pick and so on. By this system it is hoped that the weaker teams will become stronger with the addition of the more talented players and will thereby make for a better balanced league. ${ }^{26}$

The effect of the draft system has been virtually to eliminate bonuses to a signing player. Before the draft system was in existence, a player was often paid a bonus by the team who signed him as an added incentive to sell his services to that team. When two or more teams were after an exceptional athlete, that athlete's bargaining position for bonuses, as well as for salary, was very strong. However, the introduction of the player draft system reduced the number of potential employers available to the athlete to on $\mathrm{e}^{27}$ which, needless to say, destroyed his bargaining power as well as his right to select his employer. A further effect of this draft is

25 Gallagher, Contractual Rights and Duties of the Professional Athlete, (1973) Dickinson Law Roviow 352 at 389.

24 Mackey v. N.F.L. Civil No. 4-72-277 (D. Minn. filed May 23, 1972).

2s Foley, Antitrust and Professional Sport: Does Anyone Play By The Rules of The Game?, (1973) 22 Catholic University of America Law Review 403 at 416. [Editorial note: The World Football League was not considered.]

36 Supra, n. 23 at 395.

27 The Supreme Court in Timken Roller Bearing Co. v. United States 341 U.S. 593 (1951), found a similar noncompetitive agreement per se illegal. 
to force the player to play for an employer selected for him at a salary chosen by the employer, if he is to play at all. It is submitted that such a practice is in violation of antitrust policy. ${ }^{28}$

The draft, which ostensibly was created to equalize player talent and avoid bidding wars that prohibited effective competition for the new players by the poorer clubs, has eliminated economic competition for new players and in turn has taken from the player any economic leverage he might have had. ${ }^{29}$

This draft system exists both in the United States and Canada. The World Hockey Association has a slightly different draft system, which I shall examine when discussing the sport of hockey later in the paper. To my knowledge, the only time the draft system has been seriously challenged was in the recent case of Denver Rockets v. All Pro Management, Inc., ${ }^{30}$ which will be discussed under the heading of basketball.

\section{Blacklisting}

Blacklisting is a means by which club owners enforce their club rules as well as other restrictive devices, e.g. the reserve clause, employed in professional sports. Simply stated, the blacklist is the banning of a player from a league. Its existence has been justified as an effective means of preserving league integrity. It has been used to maintain public respect for professional sports by the elimination of gamblers; 31 however, it has also been used improperly by various leagues. Professional football owners in the U.S. reportedly blacklisted Bernie Parish, former All-Pro, for attempting to organize players into a union. ${ }^{32}$ Players have also been blacklisted for performing in a competitive league. ${ }^{33}$

The blacklist involves antitrust problems, since it entails the use of monopoly power to force the elimination of commercial activity, in that the teams agree not to allow a certain player to remain in the league. However, its use also involves limitations upon the personal freedom of the players. It is a system of private criminal law, practised without procedural safeguard at the fiat of the owners. Since there is no precise definition of what constitutes an activity which is punishable by blacklisting, any innocent activity by the player which does not meet with owner satisfaction may fit into the category. ${ }^{34}$

Therefore, as if the contractual restrictions on a professional athlete in Canada and the U.S. are not enough, he must also contend with the blacklist, a method by which the contractual restrictions are enforced.

\section{Negotiation List}

To the best of my knowledge, the negotiation list is indigenous only to Canada and the Canadian Football League. It works as follows: A club is informed by its scouts that a particular player in Canada or the U.S. is a potential prospect and is not under contract. The player's name

\footnotetext{
2s Schneiderman, Professional Sport: Involuntary Servitude and The Popular Will, (1971) 7 Gonzaga Law Review 63 at 73.

29 Supra, n. 25 at 416.

30325 F. Supp. 1049 (1971). The case was concerned with litigation between Spencer Haywood, The National Basketball Association and the Denver Rockets.

31 Molinas v. N.B.A. 190 F. Supp. 241 (S.D. N.Y. 1961).

32 (1967) 81 Harv. L. Rev. 418 at 426.

33 Martin v. National League Baseball Club 174 F. 2d 917 (2d Cir. 1949).

34 Supra, n. 25 at 418.
} 
(each team signs approximately 20 persons) ${ }^{35}$ is then placed with the Registrar of the C.F.L. and that club then acquires exclusive bargaining rights to that player. Often the player is not even aware that he has been spoken for until he attempts to negotiate a contract with a rival club. Negotiating rights are traded nearly as briskly as the players themselves. ${ }^{36}$ In addition, each football club in Canada is allowed to protect from the draft two players in its geographical region.

Having outlined the respective restraints that exist on the professional athlete of this continent, one cannot help but tentatively, if not absolutely, conclude that such restrictions clearly are in restraint of trade and commerce, and most certainly emasculate the liberty of an employee-athlete. The restraints just mentioned have met head-on with existing antitrust legislation in a variety of cases in all the four major professional sports. Before I examine how the law has developed in each sport, it is important to remember that when speaking of violations of antitrust law, it basically only applies to United States jurisprudence because Canada has no antitrust legislation which deals with the service industry. Also, the term antitrust violation is used to include any or all of the restraints mentioned.

\section{APPLICABILITY OF RESTRAINTS TO THE MAJOR SPORTS}

\section{Baseball}

Professional baseball employs the reserve system in its most classic form and because of its onesidedness directed against the player, it is not surprising that repeated challenges have been made in the courts of the United States ${ }^{37}$ challenging its validity vis-à-vis antitrust laws.

The first Supreme Court decision regarding the applicability of the antitrust laws to professional baseball was rendered in 1922. In Federal Baseball Club v. National League, ${ }^{38}$ the plaintiff was a member of the Federal League, an organization which had attempted to compete in major league baseball with the National League. In a unanimous decision delivered by Holmes J., the Supreme Court held that the antitrust laws were inapplicable because those laws related only to activities constituting interstate commerce and baseball was held to be a noncommercial activity; the factor of interstate transport of the teams being merely incidental.39 Thus baseball was granted an all-encompassing exemption from the application of federal antitrust laws.

This same problem arose again in 1953 in Toolson v. New York Yankees. ${ }^{40}$ In a 7-2 decision, the Court relied upon supposed Congressional intent and the doctrine of stare decisis in upholding the earlier decision in Federal Baseball. The majority stated:41

In Federal Baseball Club of Baltimore v. National League of Professional Clubs ... this Court held that the business of providing baseball games for profit between clubs of professional baseball players was not within the scope of the federal antitrust laws. Congress has had the ruling under consideration but has not seen fit to bring such business under these laws by legislation having prospective effect. The business has thus been left for thirty years to develop, on the understanding that it

3s Discussion with an officer of the Edmonton Eskimos football club.

36 Lamoureux, Unreasonable Restrictions Upon the Professional Athlete. (1971) at 15.

37 There are no reported Canadian cases on baseball's reserve clause.

38259 U.S. 200, 42 S. Ct. 465,66 L. Ed. 898 (1922).

39 Supra, n. 12 at 2.

10346 U.S. 356,74 S. Ct. 78,98 L. Ed. 64 (1953).

1 Supra, n. 12 at 3. 
was not subject to existing antitrust legislation. The present cases ask us to overrule the prior decision and, with retroactive effect, hold the legislation applicable. We think that if there are evils in this field which now warrant application to it of the antitrust laws it should be by legislation. Without re-examination of the underlying issues, the judgments below are affirmed on the authority of Federal Baseball Club of Baltimore v. National League of Professional Baseball Clubs, supra, so far as that decision determines that Congress had no intention of including the business of baseball within the scope of the federal antitrust laws.

With the Toolson decision, baseball's antitrust exemption became further solidified. However, since that decision, other cases in other sports challenged the reserve system and the courts did not follow Federal Baseball and Toolson. They will be dealt with later in the paper.

The latest case to contest baseball's reserve system was Flood v. Kuhn.42 After playing twelve years with the St. Louis Cardinals, Curt Flood was traded to the Philadelphia Phillies in October 1969. Because he was not consulted, he requested of the commissioner of Baseball, Bowie Kuhn, that he be made a free agent for the purpose of contracting with some other team. Flying right into the teeth of the reserve clause, Flood filed suit in the Federal Court for the Southern District of New York, charging violations of the federal antitrust laws and civil rights statutes, violations of state statutes and the common law, and the imposition of a form of peonage and involuntary servitude contrary to the Thirteenth Amendment and federal statutes. ${ }^{43}$

Despite an attempt to cover every possible legal angle, Flood could not dislodge the court rulings that baseball's reserve clause was exempt from antitrust laws. After an unsuccessful appeal ${ }^{44}$ in the State of New York, the Supreme Court of the United States reviewed the case and by a vote of 5 to 3 affirmed the lower court rulings. ${ }^{45}$ Blackmun J., wrote the majority opinion, and stated that professional baseball is indeed a business engaged in interstate commerce, disagreeing with the statement to the contrary in the Federal Baseball case. The Court recognized that exempting baseball's reserve clause from antitrust regulation was an "aberration", as other professional sports which operated interstate were so regulated. However, this exception was excused on the merit of stare decisis and, since baseball was "unique in its characteristics and needs", it could not be affected by antitrust laws. As a last "rationale" for its decision, the Court held that only Congressional legislation could change the status of the reserve clause vis-a-vis antitrust laws.

No doubt the Supreme Court was concerned with the possible confusion and retroactive problems which would have been created by declaring baseball subject to antitrust legislation, but I cannot help but think that two of the dissenters, Douglas J. and Brennan J., had the right approach. They said the Court should act as if the slate were clean, in which event they were certain that baseball would be held subject to antitrust regulation.

By the Flood decision, only Congress can now change the current policies, unless, the ballplayers can negotiate some settlement for themselves. The last alternative would appear to be the most feasible as Congress has remained inactive since the Toolson case in 1953. Since that decision, over fifty unsuccessful bills have been introduced in Con-

12316 F. Supp. 271 (S.D. N.Y. 1970).

43 Supra, n. 13 at 568.

4443 F. 2d. 264 (1971).

is 404 U.S. 880 (1972). 
gress to challenge baseball's antitrust exemption. The mere fact that the Supreme Court has called baseball's status an "aberration" leads one to the conclusion that the reserve system does not measure up to legal standards. ${ }^{46}$

It would therefore seem that professional baseball players both in Canada and the U.S. are the victims of a "legal anomaly" with little recourse in determining their liberty. The reserve clause, which can be renewed every year at $80 \%$ of the original salary, may thereby keep a player perpetually in the service of one club, clearly a gross restraint of trade and a denial of a man's liberty to seek employment.

\section{Football}

Football, though structured very much like baseball, does not enjoy exemption from antitrust laws. As mentioned earlier, football utilizes an option clause which we saw had a very practical effect of greatly restricting a player's liberty.

In researching this area, it is interesting to note that the validity of football's option clause has been directly challenged only once and it was held 47 that a one year restriction could not be construed as a restraint of trade in violation of the Sherman Act. The club still has the option of automatically renewing the player's contract for one year at $90 \%$ of the salary paid the previous year. ${ }^{48}$

The option clause has quite naturally been challenged in concert with an action claiming that football is not exempt from antitrust laws. The landmark American case subjecting football to the provisions of the Sherman Act was the Supreme Court decision of Radovich v. National Football League.49

In 1946, Bill Radovich was an All-Pro guard with the Detroit Lions, a member of the National Football League. That year he asked for a transfer from the Lions to the N.F.L. club in Los Angeles because of the illness of his father. The Lions refused the transfer, and Radovich broke his player contract by signing with and playing the 1946 and 1947 seasons for the Los Angeles Dons, a member of the All-American Conference, a league which folded in 1950. In 1948 the San Francisco Clippers, a member of the Pacific Coast League which was affiliated with, but not a competitor of, the National Football League, offered to employ Radovich as a player-coach. However, the N.F.L. advised the team that Radovich was blacklisted and any affiliated club signing him would suffer severe penalties. Radovich brought a suit for treble damages, charging violations of Section 1 and 2 of the Sherman Act, because of an alleged conspiracy among the members of the N.F.L. to monopolize commerce in professional football and to boycott the AllAmerican Conference and its players with a view toward its destruction. The lower court dismissed the action on the authority of Federal Baseball and Toolson.50

At the time of the Radovich case, each National Football League team used a standard player contract which prohibited a player from signing with another club without the consent of the club holding the

\footnotetext{
16 Supra, n. 13 at 570.

17 Dallas Cowboys Football Club v. Harris 348 S.W. $2 d .37$ (Tex. Cir. App. 1961).

4s See Appendix I-8. 10 Standard N.F.L. Player Contract.

4932 U.S. 445, 77 S. Ct. 390 1 L. Ed. 2d. 456 (1957).

so Supra, n. 12 at 6-7.
} 
player's contract. These contracts were enforced by an agreement among the clubs to blacklist any player violating them and to visit severe penalties on recalcitrant member clubs. Such restrictions, which bound a player to his team in a manner similar to those which have always been applied in baseball, would almost certainly be violative of the Sherman Act, if the particular sport were held subject to the antitrust laws. The Court did not rule on the legality of the specific restrictions employed by the National Football League, but left that determination to the lower court on a retrial of the case. The retrial apparently never came to pass, however, so there was no ruling as to the validity of these restrictions. ${ }^{51}$

The primary importance of the Radovich case was the court's holding as to whether football enjoyed a blanket exemption from the antitrust laws similar to that enjoyed by baseball. The Supreme Court reversed the lower court and held that professional football was not exempt from the antitrust laws.52 Speaking for the majority, Clark J. stated:53

... Since Toolson and Federal Baseball are still cited as controlling authority in antitrust actions including other fields of business, we now specifically limit the rule there established to the business of organized professional baseball.

This decision seems to have created a great inconsistency with the previous precedent in baseball, since it is virtually impossible to distinguish between the two sports. Both are team sports, both are organized into leagues, both find it necessary to act in concert to make the teams relatively well-balanced and both employ similar restrictions to accomplish this purpose. One can only conclude that the court in this case took a realistic approach to the baseball "dilemma" and would not permit such to arise in football.

Football also employs a player draft system in the States and operates in the manner earlier set out. It quite easily could be argued that the draft in this sport violates antitrust legislation, yet it has never been challenged, to my knowledge.

\section{Canada}

The Canadian Football League (C.F.L.) is structured in many ways like its U.S. counterpart. There exists a draft of Canadian college players; those players must sign a standard player contract, ${ }^{54}$ which contains a number of restrictions, including the option clause, ${ }^{55}$ which effectively makes him a chattel of his club.

Parliament has adopted a hands off antitrust policy toward the operation of Canadian football. Since the Combines Investigation Act does not apply to services, though fairly similarly worded to the Sherman Act, the players have been left with little legal recourse on which to base a case. Consequently, they must accept the reality of the draft, the clubs' complete right to transfer the contract, the option clause, and numerous other restrictions.

There have been a few Canadian cases challenging the option clause, but the cases in which the Canadian courts have considered the option clause have been in respect of the option clause of the N.F.L. Standard

3) Id. at 7.

32 Id. at 7 .

s3 352 U.S. 445 at 451 (1957).

st See Appendix I-Standard C.F.L. Contract.

ss 8.15 C.F.L. contract. 
Player's Contract and the breach of the option provision by a player. The Canadian option clause is identical to the N.F.L.'s and its actual effect in Canada is the same as its American counterpart. Because of the apparent blacklisting practice among C.F.L. teams, the player who plays out his option will be unable to negotiate his services with another C.F.L. club. Of course, that player may go to the U.S., which many have done. In Detroit Football Co. v. Dublinski ${ }^{56}$ the Ontario Court of Appeal held:57

Contracts in the field of professional sports stand in no different position than contracts in any other commercial venture. If either of the parties breaks the contract, he becomes liable for such damages as may be proved against him.

Thus, where Dublinski ignored a letter by the Detroit Lions advising him that they were exercising their option as set out in the option clause, and he proceeded to sign and play football with the Toronto Argonauts of the C.F.L. during his option year owing to Detroit, the court held that he had breached the renewal contract, i.e. the option clause, and was held liable for damages to the Detroit Lions. The Lions also sought to impose an interim injunction to prevent Dublinski from playing with Toronto during the 1955 season, but because the action did not come to trial until March, 1956, the issue of an injunction was academic because the court could not restrain the defendant from playing in a period that had passed.

In 1951, the Manitoba King's Bench dealt with two contractual problems with regard to professional football players. In Reeves et al v. Huffman ${ }^{58}$ the plaintiff football club had contracted with the defendant for his services as a player. The contract contained an option clause, which the club sought to renew for the 1951 season. Prior to the expiration date and before the start of the option year, the club wrote the defendant saying, "We are enclosing your contract for $1951 \ldots$ the club is renewing your contract ... on the same terms ... as provided in the enclosed contract for the 1951 season." This contract contained a new option clause which would have bound the defendant for the 1952 season and consequently Huffman refused to sign. The court held that the plaintiff club had not exercised their right pursuant to the option clause, but rather had offered the defendant a new and different contract, an offer he did not accept. The action was dismissed.

In Philadelphia Eagles, Inc. v. Armstrong, 59 the defendant was under contract to the plaintiff team, which sought an injunction to restrain Armstrong from playing for the Winnipeg Blue Bombers in 1951. By the option clause, Armstrong was bound to play the 1951 season for Philadelphia. However, the defendant received a circular letter from the plaintiff, calling the players into training camp, which contained the following sentence: "Please understand that only those who have signed contracts will be permitted to report ...." The court ${ }^{60}$ interpreted this statement as saying to the defendant, "If you do not sign a new standard contract form you may not go to training camp; and we will not pay you, and we will not perform any of the obligations imposed on us under your contract with us." The Court went on to say that this was a

so (1957) 7 D.L.R. (2d) 9.

$37 \mathrm{Id}$. at 16.

s8 (1951) 3 W.W.R. (NS) 176, 59 Man. R. 268, (1952) 4 D.L.R. 324.

s9 (1951) 3 W.W.R. (NS) 637, (1952) 1 D.L.R. 332.

Bo Id. at 644 . 
repudiation by the plaintiff of the existing contract and since the defendant elected to accept the repudiation, he had the right to do so and treat the contract as at an end.

The courts in both these cases enunciated their decisions on what appears to be a matter of contractual interpretation, ${ }^{61}$ without ruling on the option clause itself. If anything, they recognized the legal validity of the option clause rather than challenging it as being in restraint of trade. Therefore, even if Canada were to have antitrust legislation in the area of sports on which to base a case, these decisions would ultimately prove to be of little value in enunciating a restraint of trade argument. Although purely a matter of conjecture on my part, it seems that perhaps the courts, though recognizing the legality of the option clause, were most reluctant to see it imposed on the athletes in question.

If we conclude that the aforementioned Canadian cases appear unhelpful, perhaps the common law of the master-servant relationship may prove beneficial to a restraint of trade argument. It is clear that a master cannot restrain his servant from using his own skill to compete against the master, even though that skill was learned from the master. ${ }^{62}$ To establish that he has an interest meriting protection, the master must show either that the servant has learned the master's trade secrets, or that the servant has acquired influence over the master's clients or customers. ${ }^{63}$

In an English football case, ${ }^{64}$ Wilberforce J. said that the "retain and transfer" system (somewhat analogous to the North American reserve system) which the defendant company and league employed, could not be said to be needed to protect trade secrets or prevent the plaintiff from canvassing the defendant's old customers. Further, the Court held that (1) the retention provisions, which operated after the termination of the player's employment, and not as the exercise of an option causing the employment to continue, did substantially interfere with the player's right to seek employment and therefore operated in restraint of trade; (2) that the system was not a reasonable one to protect their interests; and (3) that such contract as existed between the parties threatened the plaintiff's liberty in seeking employment which was a matter of public interest. Consequently, the system was held invalid, ${ }^{65}$ not only as against his club, but also as against the Football Association and the Football League. It would be interesting to see if the reasoning of this recent English case would be accepted in a Canadian court.

\section{Basketball}

Basketball, as well, has been held not to be exempt from antitrust laws. ${ }^{66}$ The National and American Basketball Associations are structured along the lines of the N.F.L. in that they employ the same option clause, ${ }^{67}$ and the same type of player draft, except that there are two drafts-one for each league. As a matter of fact, the standard player contracts are almost identical in terms of the option clause, various other

\footnotetext{
6: Contractual interpretation also disposed of the case of Kapp v. B.C. Lions Football Club (1967) 61 W.W.R. 31.

62 Herbert Morris Ltd. v. Saxelby (1916) 1 A.C. 688.

a3 Supra, n. 2 at 381 . Also Garbutt Business College Ltd. v. Henderson et al (1939) 2 W.W.R. 276 (Alta. S.C.).

64 Eastham v. Newcastle United Football Club Ltd. [1964] Ch. 413.

6s Supra, n. 2 at 382.

66 Haywood v. National Basketball Association 401 U.S. 1204 (1971), 325 F. Supp. 1039 (1971).

s7 See Appendix I, s. 15 A.B.A. Standard Player Contract. A player recieves only $75 \%$ of his previous year's salary when "playing out his option".
} 
restrictions, and of course the club's right to assign a player's contract to another club in the league without the player's approval.

Because there are two professional basketball leagues, a player's bargaining power is initially increased to two possible employers. As a further consequence of two leagues, blacklisting is not as effective a restraint because a player, after playing out his option in one league, may "jump" to the other league without any fear of "reprisal". It must be noted, however, that a club does have the option of renewing a player's contract for that one year and if a player does not report or play for that option year, his club may obtain an injunction to prevent him from playing anywhere else. ${ }^{68}$ There is no "Rozelle Rule" in professional basketball.

The Haywood case ${ }^{69}$ not only enunciated that the Sherman Act was applicable to professional basketball, but also challenged the legality of the entire player draft system.

There is an N.B.A. "four year college rule", which does not permit a basketball player to play with any N.B.A. team until his high school class graduates from college, regardless of the fact that a particular athlete may choose not to attend college. This provision is designed to prevent professional teams from negotiating for a ballplayer's services while he remains in school, presumably for the protection of the studentathlete. $^{70}$

Haywood signed to play professionally before the four year limit elapsed and the Commissioner of the N.B.A. sought to invoke this rule against him and obtain an injunction to prevent him from playing, as well as levy sanctions on his Seattle team. Haywood commenced an action claiming this rule was in violation of the antitrust laws and won. The Court defined the four year rule in terms of a "concerted refusal to deal", which in essence was a group boycott, and declared such to be illegal.71

In viewing the decision in this case and the player draft system in total, i.e. in all the applicable sports, it becomes evident that there is a concerted refusal to deal with an athlete who is drafted by another team, by all the league teams. This is clearly a situation wherein league teams, in concert, refuse to deal with a drafted player and, analogous to the four-year rule, the teams are group boycotting. It follows that regardless of the reasonableness or benefit of the player draft to professional team sports, under the reasoning of Haywood, such a draft is illegal per se pursuant to section 1 of the Sherman Act. ${ }^{72}$ I have bypassed much of the legal reasoning enunciated in the Haywood case, but in a nutshell, the Court concluded that the "four-year rule" suppressed or even destroyed competition, as opposed to merely regulating or promoting competition and this was declared illegal per se. Needless to say, the entire discussion of the sport of basketball is indigenous only to the States, as

so Central New York Basketball, Inc. v. Barnett 181 N.E. 2d. 506 (1961). Lemat Corp. v. Rick Barry 275 Cal. App. 2d. 671 (Ct. App. 1969).

so Supra, n. 66.

70 Garland, Procedural Safeguard Requirements in Concerted Refusals To Deal: An Application to Professional Sports, (1973) 10 San Diego Law Review 413 at 414.

7 The court in Haywood refused to extend the "test of reasonableness" to all group boycotts. This so-called rule of reason was first introduced early in the history of antitrust law by Standard Oil v. U.S. 221 U.S. I60 (1910) which sought to define antitrust violations in terms of weighing the possible justifications of an act against the potential harm which it may cause.

72 Supra, n. 70 at 423 
Canada has no such league. I took the liberty of mentioning it as part of my analysis of the restraints on professional athletes, and in view of the possible future effect the Haywood decision might have on sports in which our country is involved.

\section{Hockey}

Much closer to home is the sport of hockey. There are presently two professional leagues, the National Hockey League and the World Hockey Association both of which operate between the United States and Canada.

\section{(a) National Hockey League (N.H.L.)}

The N.H.L. employs an option system similar to football and basketball and it operates in the same manner as previously mentioned. As in other sports, the team may freely assign a player's contract to another team in the league. ${ }^{73}$

The N.H.L. also participates in a player draft, but since the foundation of the W.H.A., it is not the only employer with which a young player must deal. As in other sports, the team owners appear to utilize a blacklist in the event a player breaches his contract, but that only works within the league itself. Many N.H.L. players have jumped to the W.H.A. without a need to worry about the effect of blacklisting.

It was mentioned in Flood v. Kuhn, that hockey is also presumably subject to the U.S. antitrust laws. This observation was founded on the lower federal court decision in Peto v. Madison Square Garden Corp. ${ }^{74}$ In this case, the plaintiff claimed that the defendants, three of the member teams of the N.H.L. and the Madison Square Garden Corp., had combined to restrain trade and establish a monopoly in the operation of major league professional teams. In a hearing on a motion to dismiss, the federal District Court held that the complaint did in fact state a cause of action, without even discussing whether hockey enjoyed any type of antitrust exemption. The Court evidently felt that there was no such exemption, or else the issue was not raised, which is doubtful. ${ }^{75}$

The recent N.H.L.W.H.A. litigation ${ }^{76}$ reaffirmed the finding that hockey is subject to antitrust provisions. The U.S. District Court granted John McKenzie and the member clubs of the W.H.A. a preliminary injunction preventing the N.H.L. and its members from further prosecuting or commencing any legal action pursuant to the enforcement of the reserve clause of the N.H.L. Standard Player's Contract. (Since this case, the N.H.L. has substituted an option clause in their contracts to replace the reserve clause, which it had used for years.)

\section{(b) World Hockey Association (W.H.A.)}

In 1972, the W.H.A. was formed with teams both in Canada and the United States. Many provisions of a W.H.A. contract present a refreshing change from the system and organization of other professional sports, particularly in the area of the "reserve" system and the player draft system.

In order to establish itself quickly, the W.H.A. began offering stars of the N.H.L. fabulous salaries. To sweeten the pot, the new league produc-

\footnotetext{
73 See Appendix I 8. 11 N.H.L. Standard Player Contract.

711958 Trade Cases 69, 196 (S.D. N.Y. 1958).

75 Supra, n. 12 at 14.

76 Philadelphia World Hockey Club v. Philadelphia Hockey Club 351 F. Supp. 462 (1972).
} 
ed a uniform player's contract which contained neither an option nor a reserve clause. As opposed to the option system, the new contract produced by the W.H.A. runs for a term of one year (unless otherwise agreed), with no option to renew. Instead an arbitration system is provided $^{77}$ to aid the club and player in reaching settlement on a new contract, or failing that, to aid the player in joining a new team.78

The advantages of such a system in the context of civil liberties is apparent. Unlike the option or reserve clause, this W.H.A. system gives a professional hockey player a great deal of bargaining power. If a player is dissatisfied with the contractual terms and cannot agree to terms after arbitration, he may begin negotiating with a new team immediately. As "fair" as this procedure is, there is a form of restriction.

Whereas a player who has played out his option with a team in those 'option-clause sports' becomes free to negotiate with any other team in the league, under the W.H.A. arbitration proceedings, ${ }^{79}$ a player who fails to come to terms with his present club can negotiate only with the team that selects him in the "secondary draft". ${ }^{80}$ Yet, even the secondary draft is not all that restrictive. The W.H.A. allows a player to refuse to sign with the selecting team and re-enter the secondary draft, whereas in the ordinary type of draft, the player either signs with the team selecting him or does not play. Conceivably, a player who wants to play for a first place finisher of the previous year could keep re-entering the pool until he was selected by that team.81 The legality of this method of changing teams, of course, depends upon whether the draft system as a whole is a proper employment method or is an unreasonable restraint of trade. $^{82}$ However, when viewing the reserve and option systems, accompanied by the blacklisting used in other major sports, the W.H.A. would appear to prima facie be the least offensive system vis-a-vis antitrust policy.

Another plus in this league is that the arbitration system of the W.H.A. is not final and conclusive, as are many arbitration schemes, and thus the player is free to reject it. Moreover, the effect of the contract offered by this league is not to suppress normal competition, but to increase the ability of the player to change teams, in comparison with the ability of players in other leagues who cannot change so easily. Because the player is not bound by an option, he may reject the arbitration system completely by switching leagues at the start of the new season. ${ }^{83}$

It would therefore appear, and at present we may tentatively conclude, that the W.H.A. has employed a minimum number of restrictions capable of being considered as a restraint of trade. By their formulation, it would appear that the W.H.A. anticipated possible antitrust litigation in the future and governed their policies accordingly.

This concludes my discussion of the major restraints, mentioned earlier, and the means by which they are exercised on the four major sports being played on this continent. The confrontation between professional sports and antitrust laws has been a confusing one, to say

\footnotetext{
" See Appendix I 8. 16 W.H.A. Standard Player Contract.

78 Supra, n. 23 at 393.

79 See Appendix I s. 16.24 W.H.A. Standard Player Contract.

so See Appendix I s. 16.3 secondary draft.

81 Supra, n. 23 at 395.

82 Id. at 395.

s3 Id. at 396.
} 
the least. A series of three decisions by the Supreme Court of the United States, previously mentioned, has established that the business of baseball $^{84}$ is completely exempt from antitrust laws, while three other decisions from that Court have held that there is no such exemption for boxing, ${ }^{85}$ football $^{86}$ and basketball..$^{87}$ In addition three lower courts applied antitrust laws to hockey, ${ }^{88}$ golf ${ }^{89}$ and bowling. ${ }^{90}$

Setting aside for the moment the restraints just mentioned, we will note that the standard player contract itself is riddled with numerous provisions adversely affecting an athlete's liberties. In a fairly recent television interview, basketball star Oscar Robertson was asked to comment upon the officiating in N.B.A. games, as this was a matter of considerable public interest. Robertson replied that his contract precluded him from commenting upon the officiating. ${ }^{91}$ Such a contractual provision, with its denial of freedom of speech, must surely be unenforceable, notwithstanding claims by professional sports' bureaucrats that such a provision is necessary for "the good of the game."

Restrictions on one's "freedom" are not alien to the Canadian athlete either. As an example, I have extrapolated a few clauses from the standard player contract of the Canadian Football League.

By clause 8 , the club has the power to discipline, fine, suspend or cancel a player's contract if a player is "intemperate, immoral, careless or indifferent, or conducts himself, on or off the field, in a manner which prejudices the club." What constitutes immorality, etc. is completely up to the discretion of the club.

There can be no doubt that Mack Herron and Jim Thorpe were "cut" from the Winnipeg Blue Bombers for simple possession of marijuana, rather than for lack of talent. I would suggest that very few fans would be dismissed from their jobs for the same offence.

Clause 18 of the same contract prevents a player from "appearing on any program including radio and/or television .... or writing articles about football ..." unless given consent by the club.

Clause 19 perhaps best indicates how blatantly unfair is the professional football player's situation. To be appreciated, it is reproduced in its entirety:

19. The parties agree that the Club shall have the exclusive right to permit any person, firm or corporation to display, for publicity or commercial purposes, pictures of the player without the player receiving remuneration therefor, and the player shall not allow either gratuitously or for remuneration, any pictures of the player to be used for any publicity purposes without the consent in writing of the club first had and receiv. ed.

On viewing this clause, it is clear that any success a player achieves may go personally unrewarded, while the club may line its pockets indefinitely.

Whether or not league clubs use this clause to their financial advan-

a4 Supra, n. 42.

as United States v. International Boxing Club of New York, 348 U.S. 236, 75 S. Ct. 259, 99 L. Ed. 290 (1955).

86 Supra, n. 49.

17 Supra, n. 66.

s* Supra, n. 74.

${ }^{89}$ Deesen v. P.G.A. of America 385 U.S. 846 (9th Cir. 1966).

9o Washington State Bowling Prop. Association v. Pacific Lanes, Inc. 356 F. 2d. 371 (9th Cir. 1966) cert. den. 384 U.S. 963, 86 S. Ct. 1590, 16 L. Ed. 2d. 674 (1966).

91 Supra, n. 28 at 68. 
tage, I would nonetheless question the reasonableness of such a carte blanche provision. By such a term, the athlete has absolutely no say as to how, when, or for what price he may be rewarded for his abilities by private enterprise.

On the other side of the coin, one might well argue that a club is paying an athlete not only for his athletic prowess on the field, but also for his social attractiveness off the field. Particularly in the situation of a "big name" athlete or "superstar", a club pays a large salary with a view to being compensated for that player's presence. Hence contractual provisions to provide for that remuneration are merely a means by which a club seeks to insure a return on its investment.

I do not wish to become involved in an exhaustive analysis of all the pros and cons of the contractual provisions in the C.F.L. Standard Player Contract, but rather it is my purpose in this paper to point out a few obvious examples where an athlete's liberty is seriously impaired.

It is my opinion that the consideration given most players by the clubs is insufficient compensation for the exchange of a player's proprietary rights. It is not surprising that recently the C.F.L. Players' Association has challenged the gross inequities which exist in their standard contract.

Restrictive measures against professional athletes have been witnessed outside the contractual sphere of influence. Football star Joe Namath was once required to divest himself of an interest in a New York bistro because the football commissioner's office felt that the establishment was frequented by persons of questionable character. Football's Paul Hornung was subjected to a year-long suspension for betting-not against his team, but for it.92

With reference to the Namath situation, is the professional athlete to be treated so much like any other public figure, as opposed to just an employee, that his private life and other business activities are to come under such close scrutiny that they may cost him his job?

As to the issue of gambling, there is a strong argument to be made for the contention that gambling by athletes on games in which they compete can lead to very undesirable results, and hence should be forbidden. It is important to keep sports free from "the fix". However, is an athlete not to be permitted to make a friendly wager on the outcome of a game (which is what Hornung did) similar to a wager made between rabid fans? Betting against your own team certainly "smacks" of a possible fix, but betting for your team ought to merely be considered as displaying great confidence in your ability to win. Where to draw the line of course is most difficult, but in the Hornung situation, I feel the action of the N.F.L. in suspending him was unwarranted.

\section{LEGISLATIVE INACTION}

In the United States, the aggrieved athlete has been able to initiate a cause of action pursuant to the provisions of the Sherman Act. In many cases previously noted, some relief has been realized. However, there still remains a preoccupation by Congress to help maintain the primacy of the teams and leagues, at the expense of the athlete, all of which, I would submit, is contrary to the spirit of the Act. 
In 1961 Congress enacted legislation which granted an antitrust exemption to football, baseball, basketball and hockey with regard to the sale of television rights. Without this exemption, agreements by clubs not to sell their television rights individually would constitute an illegal combination in restraint of trade. Clearly, mergers between rival leagues which have occurred are also in violation of antitrust laws, but Congress has passed legislation to permit this. Schneiderman said: ${ }^{93}$

What tends to be ignored is the probability that the football-merger-enabling. legislation was entirely improper-that it was inconsistent with our prevailing antitrust philosophy, and that it permitted the sacrifice of the personal rights of the athletes to the financial interests of the Leagues and the team ownerships. It is submitted that the ad terrorem argument that if the merger were not authorized, spectator sport, America's favorite weekend pastime, would be threatened, was permitted to override fundamental principles of antitrust and constitutional law. Even if there were substance to the financial distress argument of the football owners, serious doubts would remain that the survival of professional football was an issue of such moment as to warrant extraordinary relief.

It may only be a matter of time before Congress will allow a similar merger between the rival basketball leagues, the A.B.A. and the N.B.A., which, as the above author maintains, is clearly an antitrust law violation.

In Canada Parliament has proven to be even more reticent in providing any effective legislation to protect the professional athlete. The criminal provision for conspiracy in restraint of trade is of virtually no value for the athlete; the current provisions of the Combines Investigation Act only cover commodities and not services. Hence that leaves no antitrust legislation at all to alleviate the plight of the Canadian professional athlete in organized sports. However, the problem has been recognized, but that, I submit, is all.

In order to rectify the deficiencies prevalent in the Combines Investigation Act, Bill C-256, otherwise known as the Competition Act, was introduced in the House of Commons in 1971 and subsequently "died". Its major purposes were to promote competition, to provide for the general regulation of trade and commerce, and to promote honest and fair dealing.

Section 19 of this proposed Act ${ }^{4}$ dealt squarely with the problems confronting the athlete. The underlying principle of this provision was to give a player the right to negotiate with a team of his choice on terms that were not restrictive and also to protect his individual rights while playing on a team. ${ }^{95} \mathrm{~A}$ qualifying section ${ }^{96}$ instructed the courts to take account of certain special circumstances and requirements encountered in sports in making their findings. ${ }^{97}$

After the Competition Act died, a new piece of legislation, Bill C-7, was introduced ${ }^{98}$ which, among other things, set out a few provisions geared towards helping the professional athlete. Though this bill died on the order table, due to the dissolution of Parliament prior to the federal election, an analysis of its pertinent sections is useful, as it may be reintroduced.

93 Supra, n. 28 at 67.

94 See Appendix II 8. 19 (1) Competition Act.

9s Explanatory Notes to the Competition Act. p. 91.

96 See Appendix II s. 19 (2) Competition Act.

97 Supra, n. 95.

9s An Act to Amend the Combines Investigation Act. 2nd Session, 29th Parliament. 1974-Bill C-7 (H. of C.). 
Under the heading of "conspiracy relating to professional and amateur sport," proposed section 32.3 states:

32.3 (1) Every one who conspires, combines, agrees or arranges with another person (a) to limit unreasonably the opportunities for any other person to participate, as a player or competitor, in professional or amateur sport or to impose unreasonable terms or conditions on those persons who so participate, or

(b) to limit unreasonably the opportunity for any other person to negotiate with and, if agreement is reached, to play for the team or club of his choice in a professional or amateur league ...

is guilty of an indictable offence and is liable on conviction to imprisonment for two years.

(2) In determining whether or not an agreement or arrangement violates subsection (1), the court before which such a violation is alleged shall have regard to

(a) whether the sport in relation to which the violation is alleged is organized on an international basis and, if so, whether any limitations, terms or conditions alleged should, for that reason, be accepted in Canada; and

(b) the desirability of maintaining a reasonable balance among the teams or clubs participating in the same league.

Though this section seems to be a positive step toward remedying the athlete's plight, a closer examination reveals a number of deficiencies.

In subsection 1 (a) and (b), the word "unreasonably" is doomed to cause the same problems as its vague and uncertain predecessor, in Bill C-256, namely "unduly". What constitutes "unreasonably" is a matter of conjecture. Do the words "terms or conditions" refer to the draft system or the option clause and are such to be considered prima facie unreasonable? Is the C.F.L. club practise of protecting two players within its geographic area from the player draft unreasonable? From the outset, the interpretation of the word "unreasonably" is likely to cause a multiplicity of problems.

Subsection 1(b) provides for a player being able to play for the club of his choice, yet the draft system permits no choice whatsoever. At first blush, strict interpretation of this subsection would make the draft system illegal, since there is an agreement or arrangement to limit a player's choice of teams; however, is the ubiquitous word "unreasonably" going to condone such an agreement?

Subsection 2(a) introduces even more uncertainty into the applicability of the entire section. The court is to take cognizance of the fact that the organization of a sport on an international level may affect the operation of Canadian law (if it were passed) on Canadian teams. How much emphasis the court should place on that matter is unclear. It would appear that Parliament is prepared to allow the laws of another country to govern Canadian teams and Canadian athletes. Should this be permitted?99

As well, subsection 2(b) falls prey to definitional problems. What exactly is meant by the words "desirability", "reasonable", and "balance" is open to question. What agreement is desirable to the player may not be desirable to the club, which in turn may not be desirable to the public

99 The two sports organized on an international basis in Canada are baseball and hockey. If subsection 2(a) were to ever become law, its effect on baseball according to Nozick would be as follows:

"To require that one team (Montreal) abide by stringent Canadian antitrust requirements not imposed on American teams by American Law, would put that team at a disadvantage to the other teams, and might result in it being rejected from the association. Therefore, it would not be in Montreal Expos' interest to apply 8. 32.3 (2)(a).

As far as hockey is concerned, the circumstances are quite different. There are eight Canadian teams in the N.H. and W.H.A. If the draft and option clause were prohibited by the new legislation, two results would arise: 1) If the American teams wanted the Canadian teams to remain in the league, the former would have to abandon the restrictive arrangements. 2) If the American teams did not lift the restrictions. then the league, Nozick suggests, would undoubtedly break up, since the American teams could not tolerate the existence of Canadian teams competing for their players' services without the usual restraints. 
at large. Hence confusion. Further, what is "balance", how is balance to be maintained-by the restrictive measures of the player draft and/or option clauses? Is balance even needed and if so, are the existing restrictions the only method by which to accomplish this? I shall discuss the issue of balance presently in more depth.

From this discussion, it appears that these provisions pay only lip service to the athlete's civil liberties and are destined to keep the present practices of big sports businesses intact. Ultimately, therefore, the enactment of Bill C-7 could leave most professional sports in Canada either largely untouched or in a state of chaos. I would submit, as a consequence of the apparent imperfections of the proposed Bill, (in the absence of revisions), that the only remaining method by which to challenge the injustices existing in sports, is to revert to the Canadian Bill of Rights. By utilizing section 1 in the context that a professional athlete's liberty to seek employment and remain employed is abrogated, I believe a strong argument could be enunciated. In the United States, Curt Flood relied on a similar argument claiming his constitutional rights were being violated. Though the American Constitution and Amendments are much more thorough and complex than is our Canadian Bill of Rights, I believe that the analogy could be argued in a court of law with great force.

\section{COMMENTS}

The general tenor of this paper has shown that the professional athlete is subject to a number of restraints not prevalent in any other employer-employee situation. It is not disputed that certain contracts contain restrictive convenants to lessen an employee's freedom; however, most if not all of the unique restraints affecting the professional athlete are unheard of in the average contractual relationship.

Let us consider the soundness of the traditional arguments relied on by the club owners in the respective sports to substantiate the existing restraints on the professional athlete.

\section{Investment Argument}

It is often argued that the unique restraints placed upon the modern athlete are a justifiable means to protect an investment since, by and large, the athletes are paid such large salaries. Some athletes are very well paid, however the majority of players do not receive "superstar salaries". Moreover, even if a few top flight players do get paid exceptionally well, why should they be treated differently than other employees or entertainers who command excellent wages?

Baseball operates on a farm club system whereby it spends money to train its players to reach a high degree of proficiency so as to play in the major leagues. The owners argue that the reserve clause is necessary because it is inequitable for a team to spend great sums of money to develop and train a player only to lose him to another team because of better contractual terms. However, how valid is this contention?

Other employers in other industries are subjected to exactly the same risk, yet they do not require a reserve clause (or option clause) to function. Any other employer who trains a person realizes that there is a possibility the trainee may leave him and if that occurs such a loss is written off as a cost of doing business. On the other hand, if an employer is pleased with his trainee and wishes to keep him on, he induces him to remain by offering good contractual terms. 
Moreover, if after a "training program" it is highly desirable to keep the former trainee for some time in order to recoup the investment, they might offer him a contract for a term of years. The employee may be induced to sign because of the security it offers him. Even if the trainee does not remain, he is seldom if ever "blacklisted" by his employer.

The analagous equivalent in sports to induce a player to remain with a club is the "no cut, no trade" contract, particularly for an exceptional player. Quite simply, if a team wishes to protect its "investment", it must be prepared to commit itself to financial terms which appeal to the player, not unlike the industrialist vis-à-vis his employee.

Generally, the lack of a reverse or option clause has not proven detrimental to other industries, so we may conclude that there is really no reason for its retention in sports.

In passing, the major fooball and basketball leagues cannot use this investment argument at all, since they spend very little in training their players. Most players come from colleges, universities, and in the case of hockey, the junior ranks, all of which function financially independent of the major teams. True, in hockey or baseball, a player may go to a farm club for "seasoning", but, I would suggest, he more than pays for his own way.

\section{Balance Argument}

Leagues also contend that "reasonable balance" is not only desirable, but necessary to facilitate the survival of the league on a commercial level. Hence the player draft is a necessary method to maintain the balance, both "financial" balance and "player-ability" balance. By financial balance, I mean approximate parity among the teams in monetary terms. Player-ability balance refers to the argument that teams that are closely matched talentwise, make for a more exciting league and hence generate greater fan support.

Two questions arise: Is "balance", either financial or ability-wise, essential, and secondly, assuming it is, are there less restrictive means by which to accomplish such besides the player draft?

When speaking of financial balance, the traditional argument of the clubs within a league, briefly stated, is this: For a league (or team) to be a profitable venture, the entertainment value of the games must be high. Without the player draft (or reserve system), the rich teams would necessarily buy all the best talent, the league structure would weaken because of a lack of competitive entertainment, fan support would evaporate, and hence, the league would collapse.

It is questionable that league domination by the richest clubs would be detrimental to the maintenance of parity among teams and thus destroy fan support. For example, the New York Yankees created a sport "dynasty" for years (no doubt because of the club's wealth) yet fan support for the losing clubs did not dwindle appreciably so as to cause the American Baseball League to collapse.

Certainly some teams in some sports moved their franchise to other cities, but I would submit such was due to the fact that the time, place and population were not condusive to operating an economically feasible venture, rather than due to a lack of fan support because of the "imbalance of the teams". Moreover, other "poorer" franchises had fine teams as well, each with its "superstars", all of which was accomplished without a player draft. 
As mentioned earlier, the player draft is not only used for supposed financial balance, but also player-ability balance. Without the draft, the argument goes, the weaker teams could never build up their strength to be a good competitor and thus the league could not attain a greater degree of balance. Initially, this argument is valid. However, a variety of factors reduce the substantiality of this contention. Poor management may, from the outset, cause problems. Moreover, just because a certain player goes to a certain team does not mean the team becomes stronger; the coaching, scouting and "spirit" of the team can all reduce the assumed strengthening of a team. Of late, most teams are trading their coveted choices for other players. In addition, the existence of the draft does not prevent so called sports "dynasties" from coming into existence. Certain teams do dominate for a time and clearly not because of the draft.

Therefore, we may well conclude that the "balance argument" does not justify the inequities in the restraint of the athletes' selling and negotiating power currently being levied by the leagues and clubs.

\section{POSSIBLE REFORMS}

Given the fact that some teams are wealthier than others, are there other less restrictive methods of insuring the existence of the poorer teams in their respective leagues? In order to keep the league thriving, the wealthier teams ought to subsidize the poorer teams thereby hopefully maintaining a good level of entertainment. Since many view the C.F.L. as creating a greater national feeling, the federal government could provide grants for the poorer teams, much as it does in other areas of entertainment. Better gate-equalization schemes could also be devised. ${ }^{100}$

Therefore, rather than using oppressive restraints on the athlete to subsidize the teams, let the teams subsidize the athletes. In other words, if all the teams were placed on an equal financial footing each team could bargain for a player's services as readily as the next team, which in turn, I submit, would remove the necessity of the player draft.

\section{CONCLUSION}

After viewing the cases and the methods by which leagues and owners "chattelize" its players, one cannot help but conclude that indeed the professional athlete is a glaring example of a contemporary slave. In viewing the professional athlete's predicament, Michael Schneiderman had this to say: 101

Although we are willing enough to recognize that the professional athlete serves as a gladiator in modern society, we are reluctant to recognize the incidents of that gladiatorial status. The gladiator was a slave who, until exhaustion or death, was used parasitically by his audience for the excitement that his physical activity provided. Because he was well-fed (for strength), given ungents for his body (for beauty) and cheered as he fought in the arena, it became convenient to pretend that the life of the gladiator was a glorious one, and that a mere slave was fortunate indeed to be ad. mitted into the gladiatorial ranks. Transliteration of the gladiatorial role into its contemporary context in professional athletics is accomplished with striking ease ....

An athlete, as a professional, should not have to work under any

100 Some clubs in the C.F.L. could begin to help themselves financially by enlarging and improving their stadiums. Not surprisingly, the teams that are always in the bad financial straits, such as Edmonton and Regina, have the smallest seating capacities in the C.F.L.

101 Supre, n. 28 at 81. 
more restraints than the lawyer, as a professional. The athlete should be permitted to choose his employer freely (and not be subjected to a choice of one or two), to leave his employment without fear of "reprisal" (blacklisting, the "Rozelle Rule"), and not be subject to other restraints because of his large salary.

Since the law as it stands provides little or no recourse to the professional athlete and the proposed provision in Bill C-7 was meaningless and of no value, the player associations and the players themselves must negotiate, arbitrate and strike, if necessary, as such ultimately is the only means by which an athlete can challenge the current suffocating stranglehold of the clubs and leagues.

\section{APPENDIX I}

\section{Some examples of Standard Player Contracts}

\section{National Football League}

\section{The Standard Player Contract of the National Football League} provides in part:

5. The Player promises and agrees that during the term of this contract he will not play football or engage in activities related to football for any other person, firm, corporation or institution, or on his own behalf, except with the prior written consent of the Club and the Commissioner....

8.... [T] The Club shall have the right, in addition to any other rights which the Club may possess, to enjoin him by appropriate injunction proceedings against playing football or any other professional sport, without the consent of the Club, or engaging in activities related to football for any person, firm, corporation, institution, or on his own behalf....

$\dot{9}$. It is mutually agreed that the Club shall have the right to sell, exchange, assign or transfer this contract and the Player's services hereunder to any other Club in the League. Player agrees to accept such assignment and to report promptly to the assignee Club and faithfully to perform and carry out this contract with the assignee Club as if it had been entered into by the Player with the assignee Club instead of with this Club.

10. The Club may, by sending notice in writing to the Player, on or before the first day of May following the football season ... renew this contract for a further term of one (1) year on the same terms as are provided by this contract, except that (1) the Club may fix the rate of compensation to be paid by the Club to the Player during said further term, which rate of compensation shall not be less than ninety percent $(90 \%)$ of the sum set in $\$ 3$ hereof ... and (2) after such renewal this contract shall not include a further option to the Club to renew the contract....

\section{American Baseball League}

\section{Baseball's Uniform Player's Contract provides in part:}

4. (a) ... The Player agrees that, in addition to other remedies, the Club shall be entitled to injunctive and other equitable relief to prevent a breach of this contract by the Player, including, among others, the right to enjoin the Player from playing baseball for any other person or organization during the term of this contract.

5. (a) The player agrees that, while under contract, and prior to expiration of the Club's right to renew this contract, he will not play baseball otherwise than for the Club, except that the Player may participate in post-season games under the conditions prescribed in the Major League Rules....

6. (a) The Player agrees that this contract may be assigned by the Club (and reassigned by any assignee Club) to any other Club in accordance with the Major League Rules and the Professional Baseball Rules.

10. (a) On or before January 15 (or if a Sunday, then the next preceding business day) of the year next following the last playing season covered by this contract, the Club 
may tender to the Player a contract for the term of that year by mailing the same to the Player at his address following his signature hereto, or if none be given, then at his last address of record with the Club. If prior to the March 1 next succeeding said January 15, the Player and the Club have not agreed upon the terms of such contract, then on or before 10 days after March 1, the Club shall have the right by written notice to the Player at said address to renew this contract for the period of one year on the same terms, except that the amount payable to the Player shall be such as the club shall fix in said notice; provided, however, that said amount, if fixed by a Major League Club, shall be an amount payable at a rate not less than $80 \%$ of the rate stipulated for the preceding year.

(b) The Club's right to renew this contract, as provided in subparagraph (a) of this paragraph 10, and the promise of the Player not to play otherwise than with the Club have been taken into consideration in determining the amount payable under paragraph 2 hereof.

\section{CANADIAN FOOTBALL LEAGUE STANDARD PLAYER CONTRACT between}

a member of the Western Football Conference Eastern Football Conference (hereinafter referred to as the "Conference"), and of the Canadian Football League,

hereinafter called the "Club."

of the city/town of

in the province/state of hereinafter called the "Player"

In consideration of the mutual and respective covenants and agreements hereinafter contained, the parties hereto hereby agree as follows:

1. The term of this contract shall be from the date of execution hereof until the 1st day of June following the close of the football season commencing in $197 \ldots$. .., subject however to rights of prior termination as specified herein.

2. The player agrees that during the term of this contract he will play football and will engage in activities related to football only for the Club and will play for the Club in all its Conference's.scheduled and play-off games, and Canadian Football League play-off games and any exhibition games for which the Club may arrange; and the $\mathrm{Club}$, subject to the provisions hereof, agrees during such period to employ the player as a skilled football player. The player agrees during the term of this contract to report promptly for the Club's training sessions and at the Club's directions to participate in all practice sessions.

3. For the player's services as a skilled football player during the term of this contract, and for his agreement not to play football, or engage in activities relating to football, for any other person, firm, Club or corporation during the term of this contract and for the option hereinafter set forth giving the Club the right to renew this contract and for the other undertakings of the player herein, the Club promises to pay the player the sum of $\$ \ldots . . \ldots \ldots \ldots \ldots$. to be payable as follows: $75 \%$ of said salary in weekly instalments commencing with the first and ending with the last regularly scheduled Conference game played by the Club during such season, and the balance of $25 \%$ of said sum at the end of the last scheduled Conference game, unless the Club shall, after its last scheduled Conference game have any Conference or Canadian Football League play-off games to engage in, in which event the remianing $25 \%$ shall be paid at the end of the last such play-off games. (Next follow provisions for bonuses).

4. The Club shall be entitled to deduct from each and every payment made under any of the provisions of this agreement, any amount required for the player's income taxes and any other deductions required or authorized by law.

4A. The Player shall participate in the Canadian Football League Pension Plan and the Club is authorized, from time to time, to deduct and remit to the Trustee such sums of money as may be required for the Player's contribution to the Plan. 
5. The Club agrees to pay the proper and necessary travelling and reasonable board and lodging expenses whenever the player is travelling in the services of the Club for games in other than the Club's home city, but when not so travelling, the player shall pay his own expenses.

6. Prior to the start of each football season, the player shall attend before the Club's medical committee for a complete physical and medical examination, and, if, in the opinion of the said medical committee, the player is not completely fit to participate in football activities, this agreement and everything herein contained, at the Club's option, shall be void and of no force and effect.

7. The player agrees to comply with all the rules and regulations now, or which may hereafter be, adopted during the duration of this contract, by the Canadian Football League and/or the Conference and/or the Club.

8. The player agrees that should he at any time or times, or in any manner, fail to comply with the covenants or agreements on his part herein contained, or any of them, or should the player at any time be intemperate, immoral, careless or indifferent, or conduct himself in such manner, whether on or off the field, as in the opinion of the Club, endangers or prejudices the interests of the Club, or fails to attain when requested, first class physical condition, or fails to maintain first class physical condition throughout the football season, then the Club shall have the right to discipline, fine, suspend for any period or indefinitely, or cancel the contract in such manner as the Club shall deem fit and proper, and in case of a fine being imposed, the Player agrees to pay such fine or the Club may deduct that amount from any salary due or to become due in payment thereof.

9. The player agrees to promptly pay any fine levied on him by the Conference or any of its properly authorized officers or its or the Canadian Football League's Com. missioner, and failing such prompt payment the Club is authorized to pay same and deduct such amount from any salary due or to become due to the player.

10. The player represents that he is and will continue to be highly skilled in all types of football team play to play football of the calibre required by the Conference and by the Club, and agrees to perform his services hereunder to the complete satisfaction of the Club and its Head Coach. If, in the opinion of the Head Coach, the player fails at any time during the term of his contract to demonstrate sufficient skill and capacity to play football of the calibre required by the Conference or by the Club, or if, in the opinion of the Head Coach, the player's work or conduct in the performance of this contract is unsatisfactory, or, where there exists a limit to the number permitted of a certain class of player, and in the opinion of the. Head Coach, the player, being within that class, should not be included amongst the permitted number, the Club shall have the right to terminate this contract upon notice to the player. It is agreed by both parties that the Club's Head Coach shall be the sole judge as to the competency and satisfaction of the player and his services.

11. Upon termination of this contract during the football season, the player shall only be entitled to receive and the Club shall only be required to pay to the player as compensation for services theretofore rendered hereunder, such portion of the total compensation for the regular season as provided in paragraph 3 hereof, as the number of the regular scheduled Conference games already played bears to the total number of Conference games scheduled for the Club for that season, and upon such termination the Club shall pay to the player the balance of such compensation as then remains owing to the player.

12. The player promises and agrees that during the term of this contract he will not play football or engage in activities related to football in Canada or in the United States of America for any other person, firm, Club or corporation except with the prior written consent of the Club, and that he will not, during the term of this contract engage in any game or exhibition of baseball, basketball, hockey, wrestling, boxing, or any other sport which endangers his ability to perform his services hereunder without the prior written consent of the Club.

13. The player hereby represents that he has special, exceptional and unique knowledge; skill and ability as a football player, the loss of which cannot be estimated with any certainty and cannot be fairly or adequately compensated by damages, and therefore agrees that the Club shall have the right, in addition to any other rights which the Club may possess, to enjoin him by appropriate injunction proceedings against playing football or engaging in activities relating to football in Canada or the United States of America, for any person, firm, Club or corporation, and against any other breach of this contract. 
14. It is mutually agreed that the Club shall have the right to sell, exchange, assign and transfer this contract and the player's services to any Club of the Conference or to any Club in a Conference affiliated with the Canadian Football League, and the player agrees to accept such assignment and to report promptly to the assignee Club and faithfully to perform and carry out this contract with the assignee Club as if it had been entered into by the player with the assignee Club instead of with this Club, and the player agrees that the assignee Club shall pay to the Club any amount owing by the player at the time of such sale, exchange, assignment or transfer and shall be permitted to deduct such amount from salary due or to become due to the player.

15. On or before the date of expiration of this contract the Club may, upon notice in writing to the player addressed to (here follows the player's address), renew this contract for a further term until the 1st day of June following said expiration, on the same terms as are provided by this contract, except that (1) the Club may fix the rate of compensation to be paid by the Club to the player during said period of renewal, which compensation shall not be less than ninety per cent $(90 \%)$ of the amount set forth in paragraph 3 hereof, and (2) after such renewal this contract shall not include a further option to renew the contract; the phrase "Rate of Compensation" as above used shall not be understood to include bonus payments or payments of any nature whatsoever other than the precise sum set forth in paragraph 3 hereof.

16. It is mutually understood and agreed that if the operation of the Conference is suspended, this contract shall immediately be terminated and the remuneration to be paid to the player shall be on the basis as provided by paragraph 11 herein.

17. The player acknowledges the right and power of the Club and/or of the Conference and/or of the Conference's or the Canadian Football League's Commissioner to fine, suspend for any period or indefinitely, and/or cancel the contract of any player who accepts a bribe or who agrees to throw or fix a game, or who, having knowledge of the same, fails to report an offered bribe or an attempt to throw or fix a game, or who bets on a game, or who is guilty of any conduct detrimental to the welfare of the Conference, or the Canadian Football League, or of professional football; and the player hereby releases the said Conference and its or the Canadian Football League's Commissioner and the Club, and every officer, director and member of the Conference, the Canadian Football League and the said Club, jointly, and severally whatsoever he may have arising out of or in connection with the decision of the Conference or its or the Canadian Football League's Commissioner or the Club in any of the aforesaid cases.

18. The player agrees that he will not make any appearances on any program, including radio and/or television, or at any function, nor will he write articles pertaining to football or assist in the coaching of any football team other than the club without the written consent of the Club first obtained.

19. The parties agree that the Club shall have the exclusive right to permit any per. son, firm or corporation to display, for publicity or commercial purposes, pictures of the player without the player receiving remuneration therefor, and the player shall not allow either gratuitously or for remuneration, any pictures of the player to be used for any publicity purposes without the consent in writing of the Club first had and obtained.

20. If the player is injured as a result of playing football for the Club, the Club will pay the player's reasonable hospitalization until discharge from the hospital, and his medical expenses and doctor's bills, provided that the hospital and doctor are selected by the Club, and provided further that the Club's obligation to pay such expenses shall terminate at a period not more then eight weeks after the injury, and the player releases the Club from any and every additional obligation, liability, claim or demand whatsoever in connection therewith.

21. It is further agreed that if the player is injured in the performance of his duties hereunder during or subsequent to the Club's first scheduled Conference game, and the injury or injuries are such as to render him, in the sole judgment of the Club's physician, unfit to play skilled football during the football season or any part thereof, the Club shall pay to the player, so long as in the sole opinion of the Club's physician the player continues to be unable to resume his duties hereunder, $100 \%$ of the salary to which the player would be entitled to pursuant to paragraph 3 hereof, if he had played in the scheduled Conference games; it being understood and agreed that this obligation shall not extent beyond the current playing season and does not include bonuses for playoff games. If, after examination by the Club's physician, the player in said physician's opinion is able to resume his duties hereunder, the player may, if he disagrees with such opinion, so notify the Club in writing within 36 hours of the examina- 
tion and may within 36 hours of such notification submit at his own expense to an examination by a physician of his choice. If the opinion of the physician selected by the player with respect to the player's physical ability to render the services required by this contract is contrary to that of the Club physician, the dispute shall be submitted to a disinterested physician to be selected by the Club's physician and the player's physician or, if they are unable to agree, by the Commissioner and the opinion of such disinterested physician shall be conclusive and binding upon the player and the Club. The expense of obtaining the opinion of such disinterested physician shall be borne by the Club if his opinion agrees with that of the player's physician and by the player if such opinion agrees with that of the Club's physician.

22. The player represents to the Club that he is not under contract or option to play football for any other Club in Canada or the United States of America during the term of this contract, and that he has no contractual obligations which would prevent him from entering into the within contract.

23. Should the player become a member of the Armed Forces of either Canada or the United States of America or retire from football prior to the expiration of this contract, or any option contained herein, and subsequently be released from the Armed Forces or return to professional football, then and in either event the time elapsed between the player's induction into the Armed Forces and his discharge therefrom, or between his retiring from professional football and his return thereto, shall be considered as tolled, and the term of this contract shall be considered as extended for a period beginning with the player's release from the Armed Forces or his return to professional football, as the case may be, and ending after a period of time equal to the portion of the term of this contract which was unexpired at the time the player entered the Armed Forces or retired from professional football; and the option contained herein shall be considered as continuously in effect from the date of this contract until the end of such extended term.

24. This agreement contains the entire agreement between the parties and there are no oral or written inducements, promises or agreements except as contained herein.

25. This agreement has been made under and shall be governed by the laws of the Province of

IN WITNESS WHEREOF the player has hereunto set his hand and seal and the Club has caused this contract to be executed by its duly authorized officer or officers this day of

A.D. 197

SIGNED, SEALED and DELIVERED in the presence of:
C̈lub

By 


\section{Basketball}

15. Option to Renew. On or before the date of the expiration of this contract, the Club may, upon notice in writing to the Player, renew this contract for the further term of one (1) year following said expiration date on the same terms as are provided by this contract, except that:

a. The Club may fix the rate of compensation to be paid by the Club to the Player during said period of renewal, which compensation shall not be less than ninety percent (90\%) of the amount paid by the Club to the Player during the preceding season, and

b. After such renewal, this contract shall not include any further option to the Club to renew the contract.

This information on the N.B.A. option system was obtained from the statement of Thomas H. Kuchel before the Subcommittee on Antitrust and Monopoly of the Senate Committee on the Judiciary in its hearings on $\mathrm{S}$. 2373 , the basketball merger bill.

\section{National Hockey League}

The National Hockey League Standard Player's Contract provides in part:

6. ... The Player therefore agrees that the Club shall have the right, in addition to any other rights which the Club may possess, to enjoin him by appropriate injunction proceedings from playing hockey for any other team....,

11. It is mutually agreed that the Glub shall have the right to sell, assign, exchange and transfer this contract, and to loan the player's services to any other professional hockey club, and the Player agrees to accept and be bound by such sale, exchange, assignment, transfer or loan, and will faithfully. perform and carry out his contract with the same purpose and effect as if it had been entered into by the Player and such other Club.

17. The Club agrees that it will on or before September 1st following the season covered by this contract tender to the Player personally or by mail directed to the Player ... a contract upon the same terms as this contract save as to salary.

The Player hereby undertakes that he will at the request of the Club enter into a contract for the following playing season upon the same terms and conditions as this contract save as to salary which shall be determined by mutual agreement. In the event that the Player and the Club do not agree upon the salary to be paid the matter shall be referred to the President of the League, and both parties agree to accept his decision as final.

\section{World Hockey Association}

16.1 If the Player and the Club fail to sign a new contract for the season following the termination of this contract before June 1 , the arbitration procedure outlined in this Paragraph 16 shall automatically go into effect.

16.2 Arbitration Procedure

16.21 On or before July 4 following the last playing season of this contract, in the event the Player and the Club fail to enter into a new contract, the Player and the Club shall each appoint one person to hear and determine the dispute preventing the signing of such new contract. If these persons are able to reach agreement on or before July 15 of the year of the dispute, no further proceedings are necessary. If they are unable to reach agreement on or before that date, then they shall immediately select a third impartial arbitrator whose decision shall be reached on or before July 31 of the year of the dispute.

16.22 Player and Club agree to arbitrate in good faith.

16.23 If the Player and the Club agree that the decision of the impartial arbitrator is fair, a new contract will be executed embodying the terms of his decision.

16.24 If either the Player or the Club disagree with the decision of the impartial arbitrator, they may refuse to enter into a new contract and the Player automatically enters into a special secondary draft pool on August 1 of the year of the dispute.

16.3 Secondary Draft

16.31 Once a Player enters the secondary draft pool, he may not sign a contract with any other club until he is drafted. 
16.32. The League will hold, in accordance with its normal draft procedure, a "secondary draft" on or about August 15 of each year. Teams will draft in the same order as in the normal yearly draft.

16.33 The Club with which the Player was under contract immediately prior to the secondary draft may not draft the player in this manner.

16.4 Subsequent Secondary Drafts

In the event the Player and the club that drafted him in the secondary draft are unable to reach an agreement by September 1, the Player will enter a pool for a new secondary draft, the date of which will be determined by the League President.

16.5 Costs of Arbitration

The costs of the arbitration, including costs expended by the President and his staff as his services are required, will be borne equally by the Club and the Player, and the Player hereby authorizes his employing club to deduct his share of the expenses from the first payment due to the Player under the next contract he signs.

\section{APPENDIX II COMPETITION ACT, Bill C-256}

19. (1) No person shall conspire, combine, agree or arrange with any other person (a) to limit unduly the opportunities for any other person to participate, as a player or competitor, in professional or amateur sport or to impose unreasonable terms or conditions on those persons who so participate, or

(b) to limit unduly the opportunity for any other person to negotiate with and, if agreement is reached, to play for the team or club of his choice in professional or amateur sport.

(2) In determining whether or not an agreement or arrangement violates subsection (1), any court before which such a violation is alleged shall have regard to

(a) whether the sport in relation to which the violation is alleged is organized on an international basis, and if so, whether any limitations, terms or conditions alleged are, for that reason, reasonable in Canada, and

(b) the desirability of maintaining a reasonable balance among the teams or clubs participating in the sport. 